\title{
Adalimumab treatment in Juvenile Idiopathic Arthritis (JIA) patients with special focus on Uveitis
}

\author{
R Joos $^{1,3^{*}}$, C Wouters $^{2}$, J Dehoorne ${ }^{1}$, D Elewaut ${ }^{1}$ \\ From 18th Pediatric Rheumatology European Society (PReS) Congress \\ Bruges, Belgium. 14-18 September 2011
}

\section{Objectives}

We performed an observational study to evaluate the efficacy of adalimumab treatment of uveitis and arthritis in patients with juvenile idiopathic arthritis.

\section{Results}

23 JIA patients with polyarticular course (initial diagnosis: 12 oligo , 2 systemic, 2 psoriatic arthritis, 4 ERA and 3 polyarticular) were treated with adalimumab. Uveitis was found in 14 patients. (SoJIA: 2/2; OligoJIA 12/12). The results of the first six months are communicated.

Ocular: During the first six months of adalimumab treatment no new uveitis episodes occurred. In all patients visual acuity was impaired during the active uveitis phase at the start of adalimumab treatment. Some patients $(5 / 14)$ recovered sight completely, but in the others impairment of visual acuity remained. The anterior chamber cellularity decreased dramatically in the first 8 weeks. Yet in three patients a low number of white blood cells was still seen after 24 weeks.

Articular: the number of active joints ranged from 0 to 5 (mean 1,30, median 2) at start, at 3 months mean $=0,70$ and median $=1$, range $0-4$ and at six months mean $=$ 0,22 , median 0 , range $0-2$. The number of joints with LOM ranged from $0-5$ (mean 1,43 , median 1 ) at start, mean 0,91 after 3 months (median 0 , range $0-5$ ) and mean 0,39 after 6 months (median 0 , range $0-4$ ).

\section{Conclusion}

Despite the limitations of a relatively small patient group adalimumab treatment shows to be beneficial in JIA patients as well on the ocular disease as on the arthritis. Especially for uveitis we need larger long-

* Correspondence: rik.joos@telenet.be

${ }^{1}$ Centre for pediatric rheumatology, Gent, Belgium

Full list of author information is available at the end of the article term prospective randomized series to draw definite conclusions.

\section{Author details}

${ }^{1}$ Centre for pediatric rheumatology, Gent, Belgium. ${ }^{2}$ Dept of pediatry, Leuven, Belgium. ${ }^{3}$ Dept of rheumatology, ZNA, Antwerp, Belgium.

Published: 14 September 2011

doi:10.1186/1546-0096-9-S1-P317

Cite this article as: Joos et al:: Adalimumab treatment in Juvenile Idiopathic Arthritis (JIA) patients with special focus on Uveitis. Pediatric Rheumatology 2011 9(Suppl 1):P317.

Submit your next manuscript to BioMed Central and take full advantage of:

- Convenient online submission

- Thorough peer review

- No space constraints or color figure charges

- Immediate publication on acceptance

- Inclusion in PubMed, CAS, Scopus and Google Scholar

- Research which is freely available for redistribution 